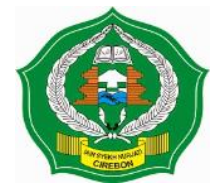

\author{
JIEM \\ (Journal Islamic Education of Management) \\ https://www.syekhnurjati.ac.id/jurnal/index.php/jiem
}

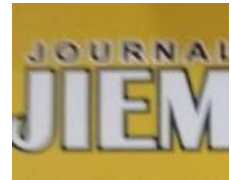

\title{
MANAJEMEN PEMBELAJARAN MATA PELAJARAN FIQH MADRASAH TSANAWIYAH NEGERI 2 KOTA CIREBON
}

\author{
Khoeron \\ IAIN Syekh Nurjati Cirebon e- \\ mail: khaeron.ak@gmail.com
}

\begin{abstract}
Abstrak
Penelitian ini bertujuan untuk mengungkap secara mendalam manajemen pembelajaran mata pelajaran fiqih Madrasah Tsanawiyah Negeri 2 Kota Cirebon. Penelitian ini ialah penelitian kualitatif naturalistik etnografi. Data itu bersumber dari wawancara mendalam, pengamatan mendalam, dan dokumentasi. Teknis analisis dilaksanakan melalui data reduction, data display, dan conclusion drawing/verification. Hasil penelitian memperlihatkan bahwa (1) Perencanaan pembelajaran fiqih di MTsN 2 Kota Cirebon meliputi program tahunan, program semester, dan silabus, serta Rencana Pelaksanaan Pembelajaran. (2) Pelaksanaan pembelajaran fiqih di MTsN 2 Kota Cirebon yang meliputi aktivitas awal, aktivitas inti, dan aktivitas penutup. Metode yang dipakai ialah metode penugasan, ceramah, diskusi, pembiasaan, tanya jawab, dan keteladanan. (3) Evaluasi pembelajaran fiqih di MTsN 2 Kota Cirebon mengukur dan menilai ranah kognitif melalui formatif tes, ulangan tengah semester, ulangan akhir semester, dan ulangan kenaikan kelas. Penilaian aspek afektif dilaksanakan dengan mengamati perilaku peserta didik di kelas secara langsung. Penilaian psikomotorik dilaksanakan melalui pemberian tugastugas praktek.
\end{abstract}

Kata kunci: Guru, Perencanaan, Pelaksanaan, Evaluasi

\begin{abstract}
This study aimed to reveal in-depth the management of learning of Islamic Jurisdiction in State Islamic Junior High School 2 Cirebon City. This research was a qualitative ethnographic naturalistic. The data was sourced from in-depth interviews, in-depth observations, and documentation. Technical analysis was carried out through data reduction, data display, and conclusion drawing /verification. The results of the study showed that (1) Islamic Jurisdiction learning planning included annual programs, semester programs, syllabi, and learning implementation plans. (2) The implementation of Islamic Jurisdiction learning included initial activities, core activities, and closing activities. The methods of learning were assignment, lecture, discussion, habituation, question and answer, and exemplary. (3) Evaluation of Islamic Jurisdiction learning for cognitive domains through formative tests, mid semester tests, end of semester tests, and class improvement tests. The assessment of affective domains was carried out by directly observing the behavior of students in class. Psychomotor assessment was carried out through the provision of practical tasks.
\end{abstract}

Keywords: Teacher, Planning, Implementation, Evaluation 


\section{A. Latar Belakang Masalah}

Madrasah adalah lembaga institusi formal yang secara sistematis menyediakan sejumlah lingkungan, yaitu lingkungan pendidikan yang memberikan sejumlah kesempatan bagi siswa untuk melaksanakan pembelajaran. Sehingga darinya perkembangan siswa diarahkan pada pencapaian tujuan pendidikan. Lingkungan tersebut diformulasikan dalam suatu kurikulum dan diwujudkan dalam proses pembelajaran (Hamalik, 2003: 3).

Mata pelajaran fiqih secara khusus mengkaji permasalahan hukum yang mengatur aspek-aspek kehidupan manusia, baik individu, masyarakat, ataupun hubungan manusia dengan Tuhan (Afandi, 2009: 3). Dalam menjalankan aktivitas beragama, umat Islam menerapkan fiqih sebagai panduannya. Tata cara bersuci, shalat, zakat, puasa, haji, infaq, shadaqah dan lain-lain telah diatur di dalamnya. Fiqih ialah undang-undang dalam beraktivitas sehari-hari yang memuat larangan, perintah, tatacara beribadah, sampai hukuman bagi pelanggar-pelanggarnya diuraikan di dalamnya.

Dalam dunia pendidikan formal, pengembangan potensi kognitif, afektif, dan psikomotorik siswa menjadi tugas pendidik (Betts, et al, 2011: 20-38; Parkison dan Thomas, 42-62; Roqib, 2009: 50). Ia dituntut untuk dapat memberikan siswa bisa pengalaman belajar dan praktik dalam proses pembelajaran. Pengalaman ialah hal-hal yang dialami melalui memecahkan, membaca, menganalisis, mencoba, merencanakan, mendengar, merasakan, melihat, membayangkan, menghayati, melakukan, menilai, dan lain-lain (Sukmadinata, 2005: 156). Proses pembelajaran dimaksudkan untuk mencapai perubahan pada siswa, dari yang tidak mengetahui menjadi mengetahui dan yang tidak mengerti menjadi mengerti, dari yang belum menguasai materi tertentu menjadi menguasai.

Dalam proses pembelajaran di kelas, sebelum pelaksanaannya ada hal yang mesti dilaksanakan oleh guru, yakni manajemen pembelajaran. Mengajar tidak hanya mentrasnfer ilmu pengetahuan, namun pula sejumlah perubahan prilaku peserta didik. Manajemen pembelajaran di madrasah tsanawiyah tidak saja sarana prasarana, namun pula menyiapkan keadaan kelas dan lingkungannya agar tercipta kenyamanan dalam belajar. Untuk itu pembelajaran mesti dikelola secara baik untuk membangun iklim belajar yang kondusif.

Tanpa suatu program yang baik sukar nampaknya tujuan pendidikan 
dapat tercapai. Oleh sebab itu, manajemen harus dirancang untuk memenuhi harapan, kebutuhan, tuntutan, dan penentu arah kebijakan sekolah untuk mencapai tujuan pendidikan. Fungsi manajemen pembelajaran ialah sebagai pedoman bagi sekolah dalam mengevaluasi dan merevisi program-program yang dinilai perlu. Hal ini sebagaimana definisi manajemen ialah proses yang meliputi perencanaan, dan kebiasaan yang dilaksanakan secara sadar, berkesinambungan dalam wujud organisasi. Adapun setiap organisasi memiliki orang yang bertanggungjawab untuk mencapai tujuan tertentu (Frederick, 2014: 563-568; Stoner, 1996: 7).

Fungsi pengawasan menyangkut penetapan standar, supervisi, dan mengukur penampilan atau implementasi terhadap standar dan memberikan keyakinan bahwa tujuan organisasi dapat tercapai. Pengawasan sangat erat hubungannya dengan perencanaan, sebab dengan pengawasan, efektivitas manajemen bisa diukur (Fattah, 1996: 2; Smits dan Moor, 2004: 1-9). Madrasah Tsanawiyah Negeri 2 Kota Cirebon ialah suatu institusi pendidikan yang di bawah naungan Kementerian Agama yang bercirikan Islam setingkat sekolah menengah pertama umum. Lembaga ini identik dengan pengintegrasian kurikulum standar sekolah negeri dengan kurikulum lokal sekolah yang berciri khas Islam. Secara umum, MTsN 2 ini menerapkan pedoman dua kurikulum, yakni Kementerian Agama dan Kurikulum Departemen Pendidikan Nasional, sehingga bagi pembelajaran fiqih yang termasuk ke dalam Pendidikan Agama Islam yang dibutuhkan oleh sekolah ini lebih banyak jika dibandingkan dengan sekolah menengah pertama pada umumnya (Mahzum, 2011: 10-11). Kenyataam secara umum, keadaan sarana prasarana MTsN 2 cukup, demikian pula dari jumlah peserta didik yang relatif banyak.

Akan tetapi di dalam penyelenggaraan pendidikannya masih banyak hambatan yang dihadapi seperti masih ada sejumlah guru yang mengajar tidak sejalan dengan kompetensinya, mereka belum mengerti pentingnya manajemen pendidikan dalam pelaksanaan pembelajaran, perencanaan pembelajaran yang kurang optimal. Hal ini dibuktikan dengan pembuatan RPP yang cenderung formalistis. Kurangnya kreatifitas guruguru MTsN 2 Kota Cirebon dalam mengajar mengakibatkan proses pembelajaran cenderung berjalan satu arah dan monoton, sehinga peserta didik cepat jenuh dalam belajar. Evaluasi pembelajaran dilakukan dengan bertahap mulai dari guru mata pelajaran, kepala 
sekolah dan supervisi dari Kemenag Kota

Cirebon belum bisa berjalan secara maksimal.

Penelitian di MTsN 2 Kota Cirebon dapat dijadikan objek penelitian sebab sekolah tersebut adalah diantara kenyataan yang terjadi pengintegrasian antara kurikulum Kemenag dengan Diknas. Khususnya dalam hal ini ialah mata pelajaran Fiqih. Berdasarkan penelitian pendahuluan di MTsN 2 Kota Cirebon pembelajaran fiqih belum terlaksana sesuai dengan yang diinginkan. Pembelajaran fiqih diharapkan bisa mempengaruhi pengetahuan, perilaku, dan kepribadian siswa sesudah mengikuti proses pembelajaran. Namun faktanya tujuan tersebut belum semuanya terealisasi, sebab masih ada peserta didik berwudhu secara asalasalan, tidak memperdulikan waktu shalat, bahkan ada juga yang saat azan berkumandang masih terus bermain. Oleh karena itu, perlu dilaksanakannya manajemen pembelajaran yang efektif agar target yang diinginkan bisa tercapai. Sukses atau gagalnya kegiatan pembelajaran sangat bergantung kepada manajemen pembelajaran yang diimplementasikan.

Berdasarkan penjelasan tersebut, dapat difahami bahwa manajemen sangat penting bagi berjalannya kegiatan pembelajaran yang baik di dalam kelas. Oleh karena itu, seorang guru mesti dapat menerapkannya sehingga bisa prestasi belajar peserta didika yang baik pula. Dari sinilah penulis tertarik untuk mengungkap secara mendalam pelaksanaan manajemen pembelajaran fiqih di MTsN 2 Kota Cirebon.

\section{B. Metode Penelitian}

Penelitian ini ialah penelitian kualitatif naturalistik etnografi. Data didapatkan ialah segala hal yang berhubungan dengan perencanaan, pelaksanaan, dan evaluasi terhadap pembelajaran Fiqih. Data itu bersumber dari wawancara mendalam, pengamatan mendalam, dan dokumentasi. Sumber data berupa informan, tempat, peristiwa, dan dokumen. Tempat penelitian di Jl. Kedung Menjangan RT.04 RW.06, Kecamatan Harjamukti, Kota Cirebon, Jawa Barat. Penelitian dilaksanakan dari 1 Agustus sampai 4 Oktober 2019. Teknik wawancara menggunakan wawancara tidak berstandar. Artinya memakai daftar pertanyaan yang tidak begitu ketat (dapat berubah) (Sutama, 2015: 232). Analisis data dilaksanakan dengan mengorganisasikan data, menjabarkannya ke dalam sejumlah unit, mensintesa, menyusun ke dalam suatu pola, menyeleksi mana yang penting dan yang hendak didalami, dan menyusun kesimpulan yang bisa disampaikan kepada orang lain. Miles dan Huberman 
menjelaskan bahwa analisis data kualitatif dilaksanakan secara interaktif dan berkesinambungan sampai tuntas atau sampai mencapai kejenuhan data. Kegiatannya dilakukan melalui data reduction, data display, dan conclusion drawing/verification (Kurniawan, 2018: 241; Sugiyono, 2015: 91).

\section{Temuan dan Pembahasan}

Perencanaan pembelajaran fiqih di MTsN 2 Kota Cirebon dilaksanakan dengan menyusun silabus dan rencana pembelajaran lalu menerapkannya di dalam kelas sehingga mengarah pada rencana pembelajaran diupayakan mencapai target. Menurut Bapak Irbono menjelaskan bahwa proses perencanaan diawali dengan penyusunan RPP, lalu program tahunan, dibagi-bagi ke program semester dan program mata pelajaran. Setiap periode tertentu, ia membuat perencanaan dalam bentuk evaluasi per semester (wawancara 5 Agustus 2019).

\section{Kalender Pendidikan di MTsN 2 Kota}

Cirebon disusun oleh pihak sekolah berdasarkan hasil musyawarah kerja tim pengembangan kurikulum. Dalam kalender Pendidikan di MTsN 2 Kota Cirebon didasarkan pada efisiensi, efektifitas aktivitas belajar mengajar.
Dalam menyusun RPP (Rencana

Pelaksanaan Pembelajaran)

guru melaksanakan sejumlah langkah, yaitu

(a)

mengidentifikasi dan mengelompokkan kompetensi yang hendak dicapai sesudah proses pembelajaran. (b) Mengembangkan bahan ajar yang hendak disampaikan. (c) Menetapkan metode yang akan digunakan dalam pembelajaran sejalan dengan mata pelajaran. (d) Merencanakan penilaian, yang menyangkut aspek psikomotorik, afektif, dan kognitif sejalan dengan tujuan pembelajaran yang hendak dicapai. Dengan adanya RPP bisa menunjang tercapainya aktivitas pembelajaran.

Untuk mendapatkan tujuan dan hasil yang diinginkan, maka dalam penerapannya guru mesti menyusun perencanaan pembelajaran fiqih atau persiapan mengajar, yakni dengan menyusun rencana pembelajaran atau RPP dan silabus yang didasarkan pada kurikulum 2013 yang berupa pemberian tugas, ringkasan pokok-pokok materi pelajaran yang berisi prota (program tahunan), dan promes (program semester).

Demikian juga dengan perencanaan pembelajaran fiqih, yang 
direncanakan mesti sejalan dengan target pendidikan. Dengan ini, maka dalam pembelajaran fiqih bisa diimplementasikan dengan baik dan bisa diajarkan secara mendetail agar peserta didik dapat menjalankannya dalam aktivitas seharihari.

Pelaksanaan Pembelajaran fiqih yang merupakan bagian dari pendidikan agama Islam di MTsN 2 Kota Cirebon menggunakan Kurikulum 2013 yang mengandung bahan ajar yang lebih bersifat tematik. Adapun MTsN 2 Kota Cirebon Pembelajaran Agama Islam mencakup Fiqih, Sejarah Kebudayaan Islam (SKI), Aqidah Akhlak, dan Qur'an Hadits. Hal tersebut sebagaimana diuraikan oleh Ja'far Musaddad selaku kepala sekolah bahwa mata pelajaran fiqih disampaikan kepada siswa, materi pelajaran yang diajarkan oleh guru untuk diolah dan selanjutnya dipahami oleh peserta didik untuk mencapai kompetensi.

Dari hasil wawancara dengan Ja'far Musaddad selaku kepala MTsN 2 Kota Cirebon menjelaskan bahwa manajemen pembelajaran merupakan bagian yang sangat penting dalam mensukseskan kegiatan pembelajaran, sebab dengan manajemen pembelajaran peserta didik bisa diawasi seluruh aktivitasnya. Dalam pelaksanaannya, manajemen kelas di MTsN 2 Kota Cirebon menyangkut penetapan kuota kelas yang berjumlah sekitar 25-30 peserta didik, pembagian ruang kelas, pembagian guru dan wali kelas serta tata tertib umum sekolah yang menyangkut jadwal jama'ah shalat dhuhur dan jam makan siang.

$\mathrm{Pa}$ Irbono menegaskan terkait pengaturan peserta didik di dalam kelas ini memakai sistem pararel dimana di setiap tingkatan kelas meliputi 4 kelas mulai kelas A-D. Kelas 7-9 menggunakan guru kelas kecuali pada mata pelajaran tertentu. Sementara itu, kelas 4-6 menggunakan guru mata pelajaran. Sebagai wujud peningkatkan pelayanan kepada peserta didik MTsN 2 Kota Cirebon menempatkan dua orang guru khusus kelas 7 yang memiliki tanggungjawab dan tugas masing-masing untuk mengawasi peserta didik ketika proses aktivitas pembelajaran berlangsung (wawancara 6 Agustus 2019).

Dengan banyaknya peserta didik di MTsN 2 Kota Cirebon yang menuntut penggunaan sistem kelas pararel, maka secara umum sekolah bertanggungjawab dalam mengatur perilaku peserta didik melalui guru. Dalam pelaksanaannya pengaturan perilaku dilaksanakan dengan pembuatan tata tertib peserta didik yang termuat pada buku harian peserta didik atau buku penghubung, serta pendalaman 
pribadi siswa dilaksanakan dengan cara berinteraksi secara langsung dengan peserta didik dan pembiasaan yang diikuti dengan konsekuensi pelanggaranya juga dipraktekkan dengan harapan peserta didik senantiasa ingat dan bisa menaatinya, dalam pengawasanya dilakukan oleh seluruh pihak khususnya wali kelas dan BK.

Berpijak pada data lapangan, peneliti menemukan bahwa metode yang diterapkan guru dalam mendalami pribadi peserta didik, yakni dengan cara mengajaknya tersebut untuk berbincangbincang seperti pendekatan sosial sehingga menghasilkan interaksi langsung antara guru dan peserta didik. Berdasarkan penjelasan Arief Ramdan selaku Waka Keurikulum dengan pendalaman seperti itu guru juga bisa tahu cara yang tepat dalam mengatur perilaku peserta didik juga bisa menjaga kedisiplinan peserta didik.

Pada garis besarnya ada sejumlah tahapan yang dilaksanakan oleh guru fiqih di MTsN 2 Kota Cirebon dalam melakukan pembelajaran, yaitu (1) Tahap sebelum pembelajaran. Tahapan sebelum pembelajaran adalah tahap yang sangat penting dalam pembelajaran. Sebab dalam kegiatan ini seorang guru dituntut untuk dapat menarik simpati peserta didik. Sebagaimana wawancara dengan bapak Irbono.
Peraturan dari pelajaran diawali dengan do'a pembukaan sejalan dengan syariat Islam dengan hafalan surat-surat pendek sejalan dengan materi fiqih yang dilaksanakan pada jam pertama pelajaran, diteruskan dengan guru melakukan pencatatan terhadap siswa yang hadir, absen dan yang datang terlambat. Kemudian guru memberi apersepsi yang mengaitkan materi yang sudah dimiliki oleh siswa dengan kompetensi yang sudah dikuasai oleh siswa (observasi 19 Agustus 2019).

Pada tahap inti pembelajaran adalah tahap inti dari sejumlah kegiatan pembelajaran yang dilaksanakan guru dengan siswa dalam mencapai suatu tujuan yang terkandung dalam RPP. Pada pelaksanaan pembelajaran, guru fiqih menggunakan pendekatan keteladanan, pendekatan emosinal, dan pendekatan rasional dengan menggunakan sejumlah metode, seperti diskusi, tanya jawab, demontrasi, role play, ceramah ini dipandang efektif dalam meningkatkan motivasi peserta didik untuk menguasai materi yang hendak dibahas pada pertemuan selanjutnya.

Bertitik tolak dari wawancara penulis dengan Bapak Irbono, beliau menjelaskan bahwa pembelajaran di MTsN 2 Kota Cirebon ini cukup efektif khususnya pembejalaran fiqih, kami di 
sini memakai metode yang tepat atau selaras dengan pelajaran yang diberikan, seperti pelajaran Sejarah Kebudayaan Islam saya memakai metode ceramah, sebab metode ceramah sendiri ialah cara penyampaian suatu materi pelajaran melalui penuturan lisan kepada peserta didik dan cara itulah yang paling awal untuk dilaksanakan dalam pembelajaran (wawancara, 30 Agustus 2019).

Berdasarkan hasil wawancara dengan Irbono bahwa pembelajaran di MTsN 2 Kota Cirebon ini sejumlah metode yang mesti digunakan oleh guru-guru dalam memberikan pelajaran, agar peserta didik mudah menerima apa yang sudah dipelajari. Dia senantiasa menggunakan metode tanya jawab dalam mengajarkan fiqih, sebab dengan metode guru dapat menggajukan pertanyaan dan siswa menjawab. Penerapan metode ini dalam pembelajaran fiqih cukup efektif. Hal ini terlihat dari pemahaman dan pengertian mengenai materi yang diajarkan akan lebih mantap. Sehingga berbagai bentuk kelemahan daya tangkap dan kesalah fahaman terhadap pelajaran bisa dihindari seoptimal mungkin (wawancara 30 Agustus

2019).

Disamping metode di atas, media pembelajaran yang dipakai juga sejalan materi yang disampaikan, kreativitas guru dalam media sangat berpengaruh dalam kesuksesan pembelajaran. MTsN 2 Kota Cirebon memfasilitasi seluruh sumber belajar sejalan kemampuan, baik sumber belajar yang berskala belajar seperti gedung sekolah yang cukup refresentatif, sarana olah raga, sarana kesenian, koperasi, UKS, perpustakaan, laboraturium komputer, dan laboratorium agama. Disamping itu guru fiqih juga dituntut oleh sekolah guna membuat media sendiri yang bisa memperlancar aktivitas pembelajaran fiqih.

Penutup Pelajaran. Dalam kegiatan ini guru fiqih memberi penguatan atau kesimpulan mengenai pembelajaran yang telah diajarkan. Hanya saja tidak seluruh guru memberi tugas seperti mata pelajaran yang lain, dengan pertimbangan sebab siswa telah terlalu banyak memperoleh tugas, khususnya yang berhubungan dengan aspek kognitif. Sedangkan dalam pembelajaran fiqih yang menjadi titik tekan ialah pengamalan dari pengetahuan yang sudah diterima oleh siswa, pada hal ini ialah aspek psikomotorik dan afektif.

Manajemen yang meliputi peserta didik adalah sebuah gerak yang tentunya berkaitan dengan fungsi manajemen, sedangkan fungsi manajemen sendiri adalah sebuah rangkaian dari sejumlah aktivitas yang mengarah pada pencapaian tujuan (Thomson, 1998: 1) 
yang direncanakan dalam pendidikan. Mendasarkan pada prinsip ini maka tahapan manajemen ialah perencanaan, pengorganisasian, pelaksanaan, pengawasan, dan pengarahan.

Peserta didik di MTsN 2 Kota Cirebon diberikan kepercayaan dan dinilai bahwa mereka dapat belajar mengatur dunianya dan percaya bahwa yang paling mengetahui dengan apa yang diharapkan oleh diri peserta didik ialah individunya sendiri, maka guru ialah sebagai monitoring yang mengawasi gerak peserta didik serta memberikan motivasi kapada peserta didik guna berpikir inovatif, kreatif, dan kritis.

Asumsi pimpinan MTsN 2 Kota Cirebon bahwa siswa akan terwujud seperti apa yang dipercaya terhadap mereka, ini sangat memungkinkan, sebab secara tidak lansung pimpinan akan memperlakukan seseorang sejalan dengan apa yang dinilai terhadap individu tersebut. Jika seorang individu dipandang baik maka akan dihasilkan tingkah laku yang mengantarkan siswa untuk berkelakuan baik, namun jika memandang siswa berperilaku kurang baik maka perilaku yang akan dimunculkan padanya juga akan menghasilkan perilaku tidak baik terhadap dirinya.

Pemberian kepercayaan penuh terhadap peserta didik secara otomatis akan mendorongnya untuk dapat berbuat dan bertanggungjawab, namun ini tidak boleh lepas dari pengawasan serta memberikan teladan untuk mendorong rasa tanggungjawab yang ada di dalam diri masing-masing individu. Asumsi para pengelola MTsN 2 Kota Cirebon bahwa siswa akan terwujud seperti apa yang dipercaya terhadap mereka, ini sangat memungkinkan sebab secara tidak langsung pimpinan akan memperlakukan seseorang sejalan dengan apa yang dinilai terhadap individu ini.

Guru fiqih memberi motivasi diselaraskan dengan keadaan siswa yang heterogen. Untuk siswa yang kurang semangat atau malas, guru memotivasi dan mengingatkan yang bersifat umum kepada para siswa yang memiliki semangat dan kelebihan, maka guru memberikan sesuatu yang terkait dengan peningkatan potensi. Sedangkan bagi siswa yang berperilaku negatif guru memberi bimbingan khusus yang bekerjasama dengan BP dan wali kelas.

Dalam evaluasi pembelajaran fiqih, efektifitas pembelajarannya tidak bisa diketahui tanpa melalui evaluasi hasil pembelajaran. Sejalan dengan kurikulum yang dikembangkan, MTsN 2 Kota Cirebon yang memuat evaluasi hasil belajar ranah psikomotorik, afektif, dan kognitif. 
Untuk merealisasikan hal ini, dilakukan:

1. Evaluasi Proses Belajar

Evaluasi pembelajaran terhadap partisipasi siswa baik secara individu ataupun kelompok selama proses belajar mengajar berlangsung. Standar yang dipakai di

MTsN 2 Kota Cirebon dalam penilaian proses bisa ditinjau dari keterlibatan siswa secara aktif baik sosial, mental, ataupun fisik dalam proses pembelajaran, selain memperlihatkan semangat belajar tinggi dan rasa percaya diri sendiri. Disamping memperhatikan keaktifan siswa mengikuti pembelajaran pada satuan pembahasan tertentu. Penilaian proses secara kognitif dilaksanakan melalui adanya tes tertulis yang berbentuk uraian (subyektif) dan pilihan ganda (obyektif). Di MTsN 2 Kota Cirebon menentukan kriteria ketuntasan minimal belajar dalam memberi penilaian tiga ranah, yakni kognitif, afektif, dan psikomotorik.

2. Evaluasi hasil belajar

Evaluasi ini ditinjau dari sisi hasil, proses pembelajaran dinilai berhasil jika terjadi perubahan tingkah laku yang positif pada diri sebagian besar atau semua siswa. MTsN 2 Kota Cirebon dalam evaluasi hasil dilaksanakan pada tengah dan akhir semester. Diselenggarakannya aktivitas evaluasi untuk memperoleh gambaran secara menyeluruh dan utuh tentang ketuntasan belajar siswa dalam waktu tertentu.

Seperti yang dijelaskan oleh Irbono bahwa pembelajaran fiqih di MTsN 2 Kota Cirebon ini senantiasa dilakukan evaluasi, untuk memperhatikan peserta didik yang kurang dalam pemahaman mengenai memahami fiqih yang sudah diajarkan di sekolah. Jika ada siswa yang nilainya di bawah standar, maka diberikan bimbingan khusus, agar ia tidak tertinggal (wawancara 4 September 2019). Evaluasi hasil belajar siswa di MTsN 2 Kota Cirebon dilaksanakan dengan sejumlah cara, yakni ujian praktek, formatif test, tugas individu, tugas kelompok, pertanyaan lisan di kelas, dan ulangan semester.

Dari hasil di atas memperlihatkan bahwa evaluasi pembelajaran fiqih di MTsN 2 Kota Cirebon memakai evaluasi dalam bentuk sumatif dan formatif. Selain itu juga evaluasi hasil belajarnya per indikator dan melalui pertanyaanpertanyaan untuk mengungkap sejauh mana 
pemahaman peserta didik terhadap apa yang telah diajarkan, dan juga dengan melihat kepribadian peserta didik dalam kesehariannya.

Manajemen pembelajaran meliputi saling keterkaitan sejumlah peristiwa, tidak saja semua aktivitas pembelajaran, namun pula faktor ekonomi, sosiologi, dan lainlain. Sistem manajemen pembelajaran ini berkaitan dengan teknologi pendidikan yang merupakan organisasi kompleks dan utuh dan mulai dari manusia, metode, informasi, mesin, keuangan, dan manajemen itu sendiri. Oleh karena itu, manajemen pembelajaran ialah proses pemanfaatan semua elemen pendidikan yang senantiasa berinteraksi untuk mencapai tujuan pembelajaran.

Dalam proses manajemen pembelajaran, guru fiqih terlibat fungsifungsi pokok yang diwujudkan oleh seorang manajer, yakni perencanaan, pengorganisasian, pelaksanaan, pembiayaan, pengawasan, dan evaluasi dalam pembelajaran. Semua fungsi manajemen ini yang menjadi fokus peneliti.

Evaluasi di MTsN 2 Kota Cirebon selama ini bisa memberikan dorongan bagi guru ataupun peserta didik, mereka meningkatkan proses berpikirnya, dan lebih giat belajar. Evaluasi terhadap peserta didik dilaksanakan untuk mengetahui sejauh mana kemajuan yang sudah mereka capai. Evaluasi tidak saja dilaksanakan oleh guru, namun juga oleh peserta didik untuk mengevaluasi diri mereka sendiri. Evaluasi diri dilaksanakan oleh peserta didik terhadap diri mereka sendiri, ataupun terhadap teman mereka. Evaluasi terhadap diri sendiri adalah evaluasi yang mendukung proses pembelajaran serta membantu peserta didik meningkatkan kesuksesannya. Oleh sebab itu, untuk mempengaruhi hasil belajar peserta didik, evaluasi mesti dilakukan dalam aktivitas pembelajaran di MTsN 2 Kota Cirebon.

\section{Penutup}

Perencanaan pembelajaran dilaksanakan dengan baik melalui penyusunan silabus program tahunan, program semesteran, dan program rencana pembelajaran serta kalender pendidikan. Dalam proses perencanaan ini telah baik, sebab telah sejalan dengan ketentuan yang ada. Pelaksanaan pembelajaran dengan melalui tes dalam berbagai bentuk. Manajemen kelas, pendekatan, metode pembelajaran, media pembelajaran yang dipakai memudahkan siswa untuk memahami materi pelajaran. Dalam pelaksanaannya pendidik juga selalu memberi motivasi kepada siswa 
dalam proses pembelajaran. Evaluasi pembelajaran dilaksanakan melalui sistem penilaian, yaitu proses pembelajaran dan hasil belajar yang meliputi tiga ranah, yakni afektif, psikomotorik, dan kognitif.

\section{Daftar Pustaka}

Afandi, M. Yazid. 2009. Fiqh Muamalah. Yogyakarta: Logung Pustaka.

Betts, Kristen, Ronnie Kramer, Linda L. Gaines. 2011. "Strategies for Meeting Current and Future Demands of Online Education Through Online Human Touch

Training and Support". International Journal of Online Pedagogy and Course Design, 20-38.

Fattah, Nanang. 1996. Landasan Manajemen Pendidikan. Bandung: Rosdakarya Offset.

Frederick, Prabha Renuka Horo. 2014.

"Organisational Behaviour and its Role in Management of Business". Global Journal of Finance and Management. 6 (6), 563-568.

Hamalik, Omar. 2003. Kurikulum Dan Pembelajaran. Jakarta: Bumi Aksara.

Kurniawan, Asep. 2018. Metodologi Penelitian Pendidikan.

Bandung: Remaja Rosdakarya.

Mahzum, Ahmad. 2011. Pengelolaan Pembelajaran Berbasis Multiple Intelligences. Surakarta: Cipta Utama.

Martin Smits dan Aldo de Moor. 2004.

"Measuring Knowledge

Management Effectiveness in Communities of Practice". Proceedings of the 37th Hawaii International Conference on System Sciences, 1-9.
Parkison, Paul dan Jeff A. Thomas. 2018. "Using Web 2.0 Tools to Engage Content, Promote Self-Efficacy, and Implications for Intentional Student

Learning". Sharma, Ramesh. Innovative Applications of Online Pedagogy and Course Design.

Hershey PA, USA: IGI Global, 4262.

Roqib, Moh. 2009. Ilmu Pendidikan Islam, Yogyakarta: LkiS.

Stoner, James A.F. 1996. Manajemen. Jakarta: PT Buana Ilmu Populer.

Sugiyono. 2015. Memahami Penelitian Kualitatif. Bandung: Alfabeta.

Sukmadinata, Nana Syaodih.

$\begin{array}{ll}\text { 2005. Landasan } & \text { Psikologi } \\ \text { Proses } & \\ \text { Pendidikan. } & \text { Bandung: } \\ \text { Rosdakarya. } & \end{array}$

Sutama. 2015. Metode Penelitian Pendidikan. Surakarta: Fairuz Media.

Thomson, Thomas M. 1998.

Management by Objectives. San Francisco, California,

United States: The Pfeiffer Library JosseyBass. 
JIEM (Journal of Islamic Education Manajemen) Vol. 3 No.2 ISSN 2549-0877 